\title{
Quality Evaluation of Kiwi Juice Coagulated Mozzarella Cheese ANUBODH KARKI ${ }^{1 *}$ AND PRAVIN OJHA ${ }^{2}$
}

\author{
${ }^{1}$ National College of Food Science and Technology \\ ${ }^{2}$ Food Research Division, Nepal Agricultural Research Council, Nepal
}

\begin{abstract}
Standardized milk having casein: fat ratio 0.92 was used for cheese preparation by using kiwi juice as a coagulant and was compared with rennet coagulated cheese. The samples were analyzed for physico-chemical properties (moisture, total solid, fat, protein, ash, calcium, fat retention, protein retention, yield) and functional properties such as meltability, stretchability, baking quality and shreddability. Significant differences ( $p<0.05)$ were found in calcium content of the cheese, color and overall sensory properties. Stretchability and shreddability in relation to functional properties were also found to be significantly different. The yield for mozzarella cheese made using rennet was higher than that of cheese made using kiwi juice as milk coagulant and also it was superior in terms of overall functional properties. It was deemed that a good quality mozzarella cheese with variant characteristics can be prepared by using kiwi juice as milk coagulant.
\end{abstract}

Keywords: Mozzarella cheese, Kiwi juice, Fat retention, Protein retention, Stretchebility

\section{Introduction}

Mozzarella cheese is a soft, unripened cheese variety of pasta-filata family (Kosikowski, 1982). This cheese is distinguished by unique plasticizing and kneading treatment of the fresh curd in hot water, which imparts to the finished cheese its characteristic fibrous structure, melting and stretching properties (Kindstedt, 1995). It is a semi-soft cheese. Due to its high moisture content, it is traditionally served the day it is made, but can be kept in brine for up to a week, or longer when sold in vacuum-sealed packages. Low-moisture mozzarella can be kept refrigerated for up to a month. Mozzarella of several kinds are used for most types of pizza, lasagna, or served with sliced tomatoes and basil (Anon, 2009). Utilizing kiwi juice as a milk coagulant for cheese production can be done to produce a $100 \%$ lactovegetarian friendly cheese along with providing a viable product diversification alternative. The $\mathrm{pH}$ and temperature dependency of the enzyme present in kiwi fruit and its stability profiles are compatible with the physiochemical criteria necessary during the cheese making procedure (Lo Piero et. al., 2011). The amount of enzyme is greater in quantity with a higher level of activity in ripe kiwi with 299 $\mathrm{U} / \mathrm{mg}$ against total casein. This represents a potential use for overripe or discarded fruit as well.

\footnotetext{
*Corresponding Author: anubodh.k@gmail.com
}

Furthermore, the preparation of the kiwi juice is easier, faster and cheaper than other enzyme coagulants (Lo Piero et al., 2011). The major objective of this work is to compared kiwi juice coagulated mozzarella cheese with rennet coagulated cheese to see the potentiality of kiwi juice as a coagulant and to prepare a $100 \%$ lacto-vegetarian friendly cheese.

\section{Materials and methods}

Kiwi fruit was peeled and then pulped. The juice obtained was then centrifuged at $3000 \mathrm{rpm}$ for 10 minutes. Thus obtained supernatant was filtered through a muslin cloth to remove suspended particles and clear juice was obtained as described by Lo Piero et al. (2011). Protein assay of the kiwi juice thus obtained was performed by the method described in Lowry et.al., (1951) using Bovine serum albumin(BSA) as a standard protein. The absorbance reading at $750 \mathrm{~nm}$ was taken in Jenway 6305 UV/Vis Spectrophotometer. The protein content was found to be $1.97 \mathrm{mg} / \mathrm{ml}$ in the prepared kiwi juice. Milk-clotting activity was measured by the method described in Uchikoba and Kaneda (1996) based on the visual evaluation of the first clotting flakes appearance. It was found that $20 \mathrm{ml}$ of juice corresponding to the $39.4 \mathrm{mg}$ protein can clot 1Litre of milk in 16 minutes. 
Four liters of standardized milk were taken for each batch to prepare mozzarella cheese using rennet (Product A) and kiwi juice (Product B) as milk coagulant. The milk was assessed for cheese making and it was heated and acidified using citric acid solution $(0.5 \%)$ to set the temperature and $\mathrm{pH}$ at the optimum level for coagulum formation; $40^{\circ} \mathrm{C}, \mathrm{pH}$ 5.5 and $36^{\circ} \mathrm{C}$, pH 5.8 respectively for kiwi juice and rennet coagulated mozzarella respectively. The coagulant was then added and set coagulum was then cut, healed, stirred sequentially and whey was expelled. The mass was cooked until plastic mass was formed and washed with cold water. The cheese was molded into balls and packed in a plastic pouch.

The chemical analysis of milk namely fat, protein, acidity was determined by methods described in NDDB (2001). Protein, ash and fat in cheese were determined according to Ranganna (2000) and calcium, moisture by the method described in AOAC (2005).

The functional property, namely meltabilty was assessed by the method provided by Muthukumarappan et. al, (1999) where the cheese sample was heated in an aluminium dish in the boiling water for $5 \mathrm{~min}$. The whole assembly was covered with the plate during heating so that the steam can't escape. The increase in melted cheese area was measured on the graph paper. The ratio of the melted cheese area and original area are measured and taken as the indicator of cheese meltability.

Stretchability test was carried out based on the principle of 'stretch test' (Kosikowski, 1982) modified by Ghosh and Singh (1990) due to its simplicity. About $10 \mathrm{~g}$ cheese was taken in $250 \mathrm{ml}$ beaker containing $3 / 4^{\text {th }}$ of its volume of hot water maintained at $80-83^{\circ} \mathrm{C}$ in a water bath. It was kept in the beaker for about $3 \mathrm{~min}$. A glass rod was inserted into the molten cheese product and pulled out slowly after providing few turns by hand. Cheese thread formation was observed when the rod was observed when the rod was being gradually lifted. The length of the thread was assumed as the stretchability parameter. Longer thread indicated with unbroken strings represented better stretching characteristics.

Good shreddability is characterized by free flow of the shredded cheese and a low tendency of the cheese shreds to stick together to form balls or clumps (Fox, 2004). Cheese samples, cheese masses were taken and shredded and its ability to cut cleanly into strips of uniform dimension and susceptibility to fracture, sticking or clumping together were assessed. and scored in 5 points arbitrary numbers accordingly.

Fox, 2004 provided a simple means to assess the baking quality of cheese, where about $100 \mathrm{~g}$ of shredded cheese was topped on each unbaked pizza base, with only tomato sauce and then transferred to an oven maintained at $180-200^{\circ} \mathrm{C}$, where it is kept for about 20-25 minutes to allow melting (till the shreds fused uniformly) of cheese shreds and baking of pizza base. The baking characteristics of the cheese were assessed by the arbitrary numbers. The best baking characteristics are a representation of complete melt and no exhibition of shreds.

The meltability, stretchability, shreddability and baking quality was graded on 5 points arbitrary scale where 5 represented the best characteristics as per described by Farahani et al. (2013).

\section{Results and Discussion}

The basic cheese making protocol was employed from Fox et al., 2000 with slight modification according to Bajracharya et. al.,2000 and Farkye, 2004. In general, it was found that for a specific quantity of milk, a specific quantity of coagulant under its optimum $\mathrm{pH}$ and temperature is capable of coagulating milk. In total 6 trials were done, three with using rennet as a coagulant and another three with kiwi juice as a coagulant. The result of milk analyzed is shown in table 1 .

Table 1 Test of milk for cheese making

\begin{tabular}{ll}
\hline Tests & Results \\
\hline Fat & $3 \%$ \\
SNF & $7.45 \%$ \\
Casein & $2.76 \%$ \\
Clot on Boiling (COB) & Negative (Absence of curd) \\
Alcohol test & Negative (Absence of curd) \\
Acidity & $0.14 \%$ \\
pH & 6.6 \\
\hline
\end{tabular}

The Casein/Fat (C/F) ratio of the milk was found to be 0.92 . Milk having C/F ratio of $0.90-0.98$ is suitable for making a good quality mozzarella cheese (Bhandari, 2009).

\section{Yield and Chemical Compositions}

The yield and chemical composition of the mozzarella cheese obtained by using methods described in the methodology has been shown in table 2 .

The yield and calcium content for mozzarella cheese was found to be significantly different $(p<0.05)$ between the products and there were no significant differences in scores for moisture, total solid, fat, protein, ash in terms of physicochemical properties of cheese. Lower yield may be due to lower fat and protein recovery and losses in whey (Fox et.al, 2002). This might be due to higher fat loss during whey drainage accompanied by fat losses during stretching. Stretching causes the loss of fat from 3-7\% (Upadhyay, 1991). The properties also differed in products because of the coagulants used and were also interrelated with respect to the calcium content of the cheeses. Higher concentration of the total solid and a descendent of calcium from the kiwi fruit may be the causative agents of higher calcium content in mozzarella prepared using kiwi juice (Kosikowski, 1999). 
Karki \& Ojha: J. Food Sci. Technol. Nepal, Vol. 10 (7-10), 2018

Table 2 Chemical composition and yield of Product A and Product B

\begin{tabular}{llllllllll}
\hline Product & $\begin{array}{l}\text { Moisture } \\
\%\end{array}$ & $\begin{array}{l}\text { Total } \\
\text { Solid\% }\end{array}$ & $\begin{array}{l}\text { Fat\% } \\
(\mathrm{db})\end{array}$ & $\begin{array}{l}\text { Protein\% } \\
(\mathrm{db})\end{array}$ & $\begin{array}{l}\text { Ash\% } \\
(\mathrm{db})\end{array}$ & $\begin{array}{l}\mathrm{Ca} \\
\mathrm{mg} / 100 \mathrm{gm} \\
\text { cheese }^{\mathrm{s}}\end{array}$ & $\begin{array}{l}\text { Fat } \\
\text { retention } \\
\%^{\mathrm{s}}\end{array}$ & $\begin{array}{l}\text { Protein } \\
\text { retention } \\
\%\end{array}$ & $\begin{array}{l}\text { Yield } \\
\%^{\mathrm{s}}\end{array}$ \\
\hline $\mathrm{A}$ & 54.12 & 45.88 & 45.06 & 47.65 & 5.03 & 609.77 & 72.14 & 82.75 & 10.47 \\
& $(1.56)$ & $(1.56)$ & $(1.26)$ & $(1.42)$ & $(0.40)$ & $(1.01)$ & $(3.85)$ & $(2.5)$ & $(0.35)$ \\
& & & & & & & & & \\
$\mathrm{B}$ & 50.46 & 49.54 & 44.01 & 48.53 & 5.01 & 664.54 & 64.83 & 77.71 & 8.93 \\
& $(0.57)$ & $(0.57)$ & $(0.99)$ & $(1.58)$ & $(0.64)$ & $(1.24)$ & $(0.97)$ & $(2.1)$ & $(0.22)$
\end{tabular}

$\mathrm{db}=$ dry basis, The values in the tables are the arithmetic means of triplicates.

*Figure in the parenthesis are the standard error of the mean.

**Values in the column bearing superscript $(\mathrm{S})$ are significantly different $(\mathrm{p}<0.05)$ from each other.

\section{Functional properties}

presented in the bar diagram in figure 1.

The functional property of the mozzarella cheese prepared by using rennet and kiwi juice as coagulant has been

๑Product A $\square$ Product B
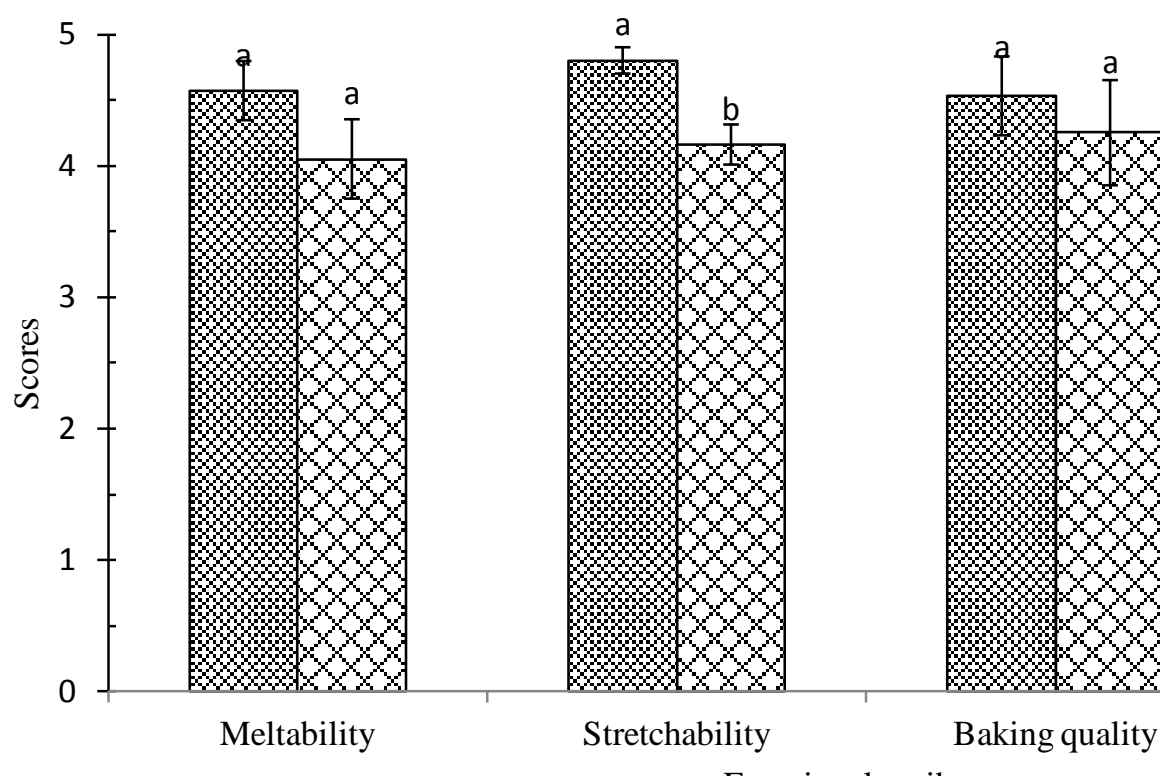

Functional attributes

Figure 1 Functional properties of mozzarella cheese

$*$ Vertical error bars represent \pm Standard Deviation of scores given by 15 panelists.

**Same alphabet at the top of the bars indicated not significantly different

The obtained result complies with the Gunasekaran et.al. (2002), who concluded cheese with greater meltabilty had higher stretchability. According to Fox et.al, (2002), the reduction of calcium results in greater number of fat globules within the protein matrix. Thus protein-protein interaction in the matrix would be reduced increasing the melting properties. The decrease in calcium concentration results in more swollen, hydrated para-casein matrix which coincides with an increase in the mean stretchability of the melted cheese, as reflected by a lower elastic shear modulus
(Fox et.al., 2002). The statistical analysis shows the two products are significantly different $(\mathrm{p}<0.05)$ in terms of stretchability. The obtained result complies with the Gunasekaran et.al. (2002), who concluded cheese with greater meltabilty had higher stretchability and thus better baking quality. Product B (kiwi juice coagulated cheese) had cleanly cut strips of uniform dimension and was not susceptible to fracturing in comparison to product A (rennet coagulated cheese) which was a little sticky and clumping within the shredded mass. The shreddability is affected by 
the ratio of solid-to-liquid fat, which decreases as the temperature is raised. The statistical analysis shows the two products are significantly different $(\mathrm{p}<0.05)$ in terms of shreddability.

\section{Conclusions}

The yield of mozzarella prepared using rennet was higher with higher moisture, ash, fat and protein and their retention in comparison to mozzarella made by kiwi juice as a coagulant. Rennet coagulated mozerella cheese was found to be superior for stretchability and shreddabilty than kiwi juice coagulated cheese. Mozzarella cheese made using kiwi juice as coagulant was comparable to rennet coagulated cheese, however, a study on effects of different additives on the performance of kiwi juice coagulated mozzarella cheese.

\section{References}

Anonymous (2009). Meeting the worldwide dairy demand. "Code for Federal Regulation, Title 21, part 133". Accessed 19th of November 2015.

AOAC (2005). Official Methods of Analysis 18th Edition. Association of Official Analytical Chemists, Washington DC.

Bajracharya, G. (2009). Personal Communication. Dairy Technologist, Chief Technical Officer. Dairy Development Corporation, Kathmandu.

Bhandari, C. (2009). Production technology of Dairy Products.Gyanjyoti, Kathmandu.pp 68-70.

Farahani, Z.K., Farahani, F.K., Yousefi, M. and Nategi, L. (2013). Comparision of different commercial cheese characteristics in Iran. European Journal of Experimental Biology 3(3): 257-260

Farkye, N. (2004). Cheese technology.Intl' Journal of. Dairy Technology, 57, 91-98.Feijoo- Siota, L., and Villa, T. G. (2011). Native and biotechnologically engineered plant.

Fox, P.F. (2004). Cheese: an overview. "In cheese: Chemistry, Physics and Microbiology, Vol (1), general aspect. P.F. Fox (Ed.), Elsever Applied Science, London.

Fox, P.F. and Cogan T.M. (2000). Cheese: Scientific Highlights of the 20th century. Proceeding of the 6th cheese symposium, Teagasc, Dublin. pp. 83.

Ghosh, B.C and Singh, S (1990), Effect of heat treatment on the quality of mozzarella cheese from buffalo milk. Indian J. Food Sci. Technol., 4, 218-220.

Gunasekaran M.M., Lidija B.,Gavrovic J., (2002). Salt in cheese "In Cheese: Chemistry, Physics and Microbiology" Vol. (1). (P.F.Fox. Ed). Elsevier Applied Science, London. pp. 79.

Kindstedt, P. S. (1995). Revised protocol for the analysis of melting properties of Mozzarella cheese by helical viscometry. J. Dairy Sci., 75, 676-682.

Kosikowski, F.V. (1982). Cheese and fermented milk foods. Edwards Bros. Inc. Michigan
Lo Piero, A.R., Puglisi, I., Petrone, G., 2011. Characterization of the purified actinidin as a plant coagulant of bovine milk.Eur.Food Res. Technol. 233, 517524.

Lowry, O.H., Roseberough, N.J., Farr, A.L., Randall, R.J., (1951). Protein measurement with Folin phenol reagent. Journal of Biochemistry. 193, 265-275.

Muthukumarappan, K., Wang, Y.C. and Gunasekaran, S. (1999). Short communication: modified schreiber test for evaluation of mozzarella cheese meltability. J. Dairy Sci., 82, 1068-1071.

NDDB, (2001). Laboratory handbook for Dairy Analysis. NDDB.

Ranganna. S. (2000). "Handbook of Analysis and quality control for Fruits and Vegetable Products" (2nded.). Tata McGraw-Hill Publishing Co., New Delhi. pp. 1038-1040.

Uchikoba, T., Kaneda, M., 1996. Milk-clotting activity of cucumisin, a plant serine protease from melon fruit. Applicable Biochemistry, Biotechnology. 56, 325-330.

Upadhyay, K.G. (2003). Essential of cheesemaking. 1st (Edn), Anand Press. Gaujrat Agricultural University, Anand. 